\title{
Harvest time: crop-reaping technologies and the Neolithisation of the Central Mediterranean
}

\author{
Niccolò Mazzucco ${ }^{1, *}$, Denis Guilbeau ${ }^{1}$, \\ Cristiana Petrinelli-Pannocchia ${ }^{2}$, Bernard Gassin ${ }^{3}$, Juan José Ibáñez $^{4}$ \\ $\&$ Juan Francisco Gibaja ${ }^{4}$
}

\section{Introduction}

Neolithic societies were defined by the development of agricultural economies not only because part of their diet was obtained from cultivated plants, but also because crophusbandry practices strongly affected people's lifestyles in a variety of ways. It is therefore unsurprising that the development and diffusion of agriculture can be studied from diverse perspectives and with different approaches, by analysing, for example, the macro- and micro-botanical remains of fruits and grains for morphometric and taxonomic variation (Colledge \& Conolly 2007) and genetic history (Mascher et al. 2016). Conversely, agriculture can be indirectly assessed through its impact on the environment and subsequent landscape modifications (Zanchetta et al. 2013; Mercuri 2014). Yet another approach explores crop-husbandry practices as reflected in changing technology. New agricultural tasks required the adaptation of existing technologies and the adoption of new tools and practices, including querns, millstones and other grain-grinding equipment, as well as artefacts and structures for grain storage, cooking and processing.

The most evident innovation in flaked stone technology associated with the Neolithisation phenomenon concerns the so-called 'glossy blades'. Early experimental and use-wear studies of these blades fed debate about the mechanisms responsible for polish formation (Anderson 1982; Unger-Hamilton 1984). More recently, however, renewed attention towards these tools and their technological, functional and geographic variability (Ibáñez et al. 2008; Maeda et al. 2016) has considered their significance in relation to economic organisation, cultural boundaries and processes of technological innovation.

1 UMR 7055 'Préhistoire et Technologie', CNRS-Université Paris Ouest Nanterre la Défense, 21 Allée de l'Université, F-92023 Nanterre cedex, France

2 Dipartimento di Civiltà e Forme del Sapere, Università di Pisa, Via Pasquale Paoli 15, 56126 Pisa, Italy

3 UMR 5608, TRACES, Université de Toulouse II-Le Mirail, Maison de la Recherche, 5 Allée Antonio Machado, 31058 Toulouse cedex 9, France

4 Institución Milá y Fontanals, Spanish National Research Council (CSIC), Calle Egipcíaques 15, 08001 Barcelona, Spain

* Author for correspondence (Email: niccolo.mazzucco@mae.u-paris10.fr) 


\section{Research objectives}

The ongoing research reported here is the result of three integrated projects: 'Diffusion of Neolithic: agricultural technologies and innovations in the Central Mediterranean', funded through a post-doctoral grant (to author N.M.) by the Fondation Fyssen; and the collective projects 'Le temps des moissons: l'arrivée des premières communautés d'agriculteurs en méditerranée centrale', funded by the Maison Archéologie \& Ethnologie, René-Ginouvès, and 'La difusión del neolítico en el Mediterráneo centro-occidental: agricultura, innovaciones tecnológicas y carbono 14-HAR2016-75201-P', funded by the Spanish Ministry of Economy and Competitiveness. The main aim of these projects is to reconstruct the technological systems related to the production and use of harvesting tools in different regions of the Central Mediterranean: the Italian Peninsula, the Dalmatian coast and Greece. The chronological framework ranges between c. 6500/6400 and 5000/4900 cal BC, from the Early Neolithic of Thessaly to the Early Neolithic of the Po Plain. These regions are crucial for understanding the mechanisms through which Neolithic lifestyles diffused across the Mediterranean and into Europe (Figure 1).

The projects focus on the following questions:

- Did the production and use of 'glossy blades' rely on a completely new technology compared to other classes of tools, such as trapezes or end-scrapers? How did Neolithic technological systems relate to those of the last huntergatherers in the same areas?

- Were technological systems organised in the same way across all the regions under study? If not, can regional differences be explained as the result of constraints, such as the quality and availability of raw materials or the type of crops cultivated? Or, conversely, are differences the result of the divergent harvesting techniques?

- If different harvesting techniques existed, can they be linked to different modes of agricultural production? Was such variability influenced by economic factors or mainly cultural ones?

- Is it possible to highlight any development or changes between the Early Neolithic and later periods?

- Can different harvesting traditions be linked to the different paths by which Neolithic communities diffused across the Mediterranean?

To answer these questions, fresh data about Early Neolithic socio-economic and cultural practices will be collected, integrating the results from the analysis of pottery assemblages, of carpological remains, of land-use patterns and radiocarbon dates.

\section{Preliminary results}

Our preliminary finds point to promising results (Mazzucco et al. 2016). It seems that at least two harvesting traditions existed in the Central Mediterranean, differing both in (C) Antiquity Publications Ltd, 2017 


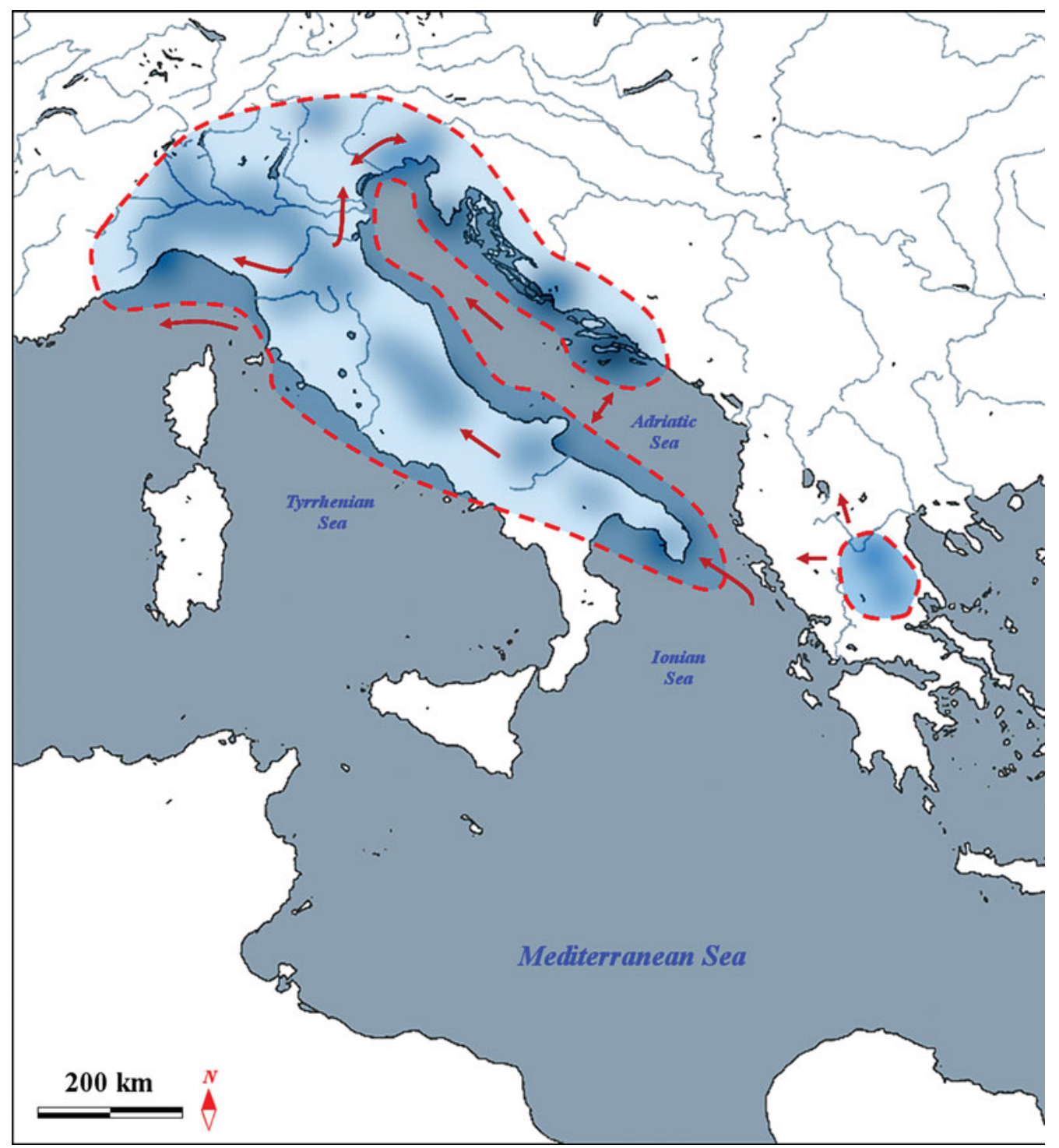

Figure 1. Geographic framework. Red dotted lines mark the area of the study. Red arrows indicate the main routes of diffusion acknowledged today. Darker blue shades indicate the areas with a major concentration of analysed sites.

terms of the technologies of sickle and reaping-knife production, and in terms of the types of agricultural product harvested (Figures $2 \& 3$ ).

Moreover, the regional differences observed seem to sustain the hypothesis of multiple Neolithisation events, linked to the expansion of groups of diverse origins. In addition to a maritime route of expansion originating from southern Italy at the beginning of the sixth millennium BC and spreading along the Tyrrhenian and Adriatic coasts, a terrestrial wave also moved across the northern Mediterranean, around the mid-sixth millennium, spreading rapidly from northern Italy towards southern France and the north-east of 
Niccolò Mazzucco et al.

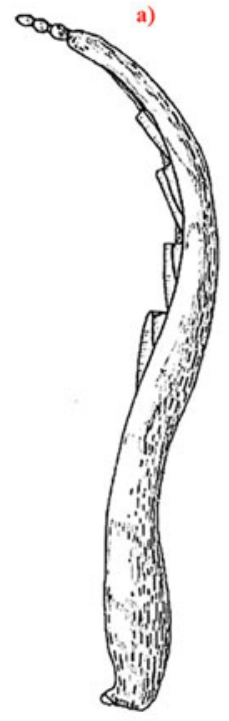

b)
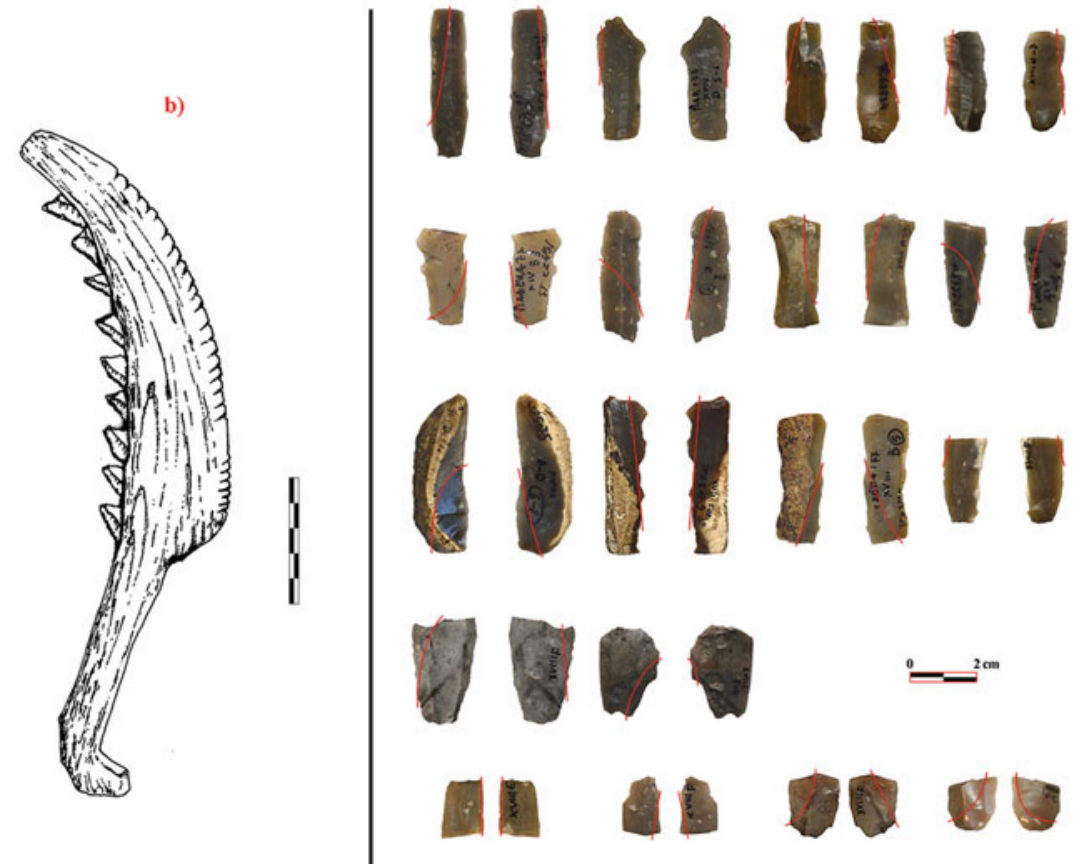

Figure 2. Examples of glossy blades for bended sickles, with: a) antler sickle from Karanovo (modified from Gurova 2014); b) wooden sickle from La Marmotta (modified from Pessina \& Tiné 2008).
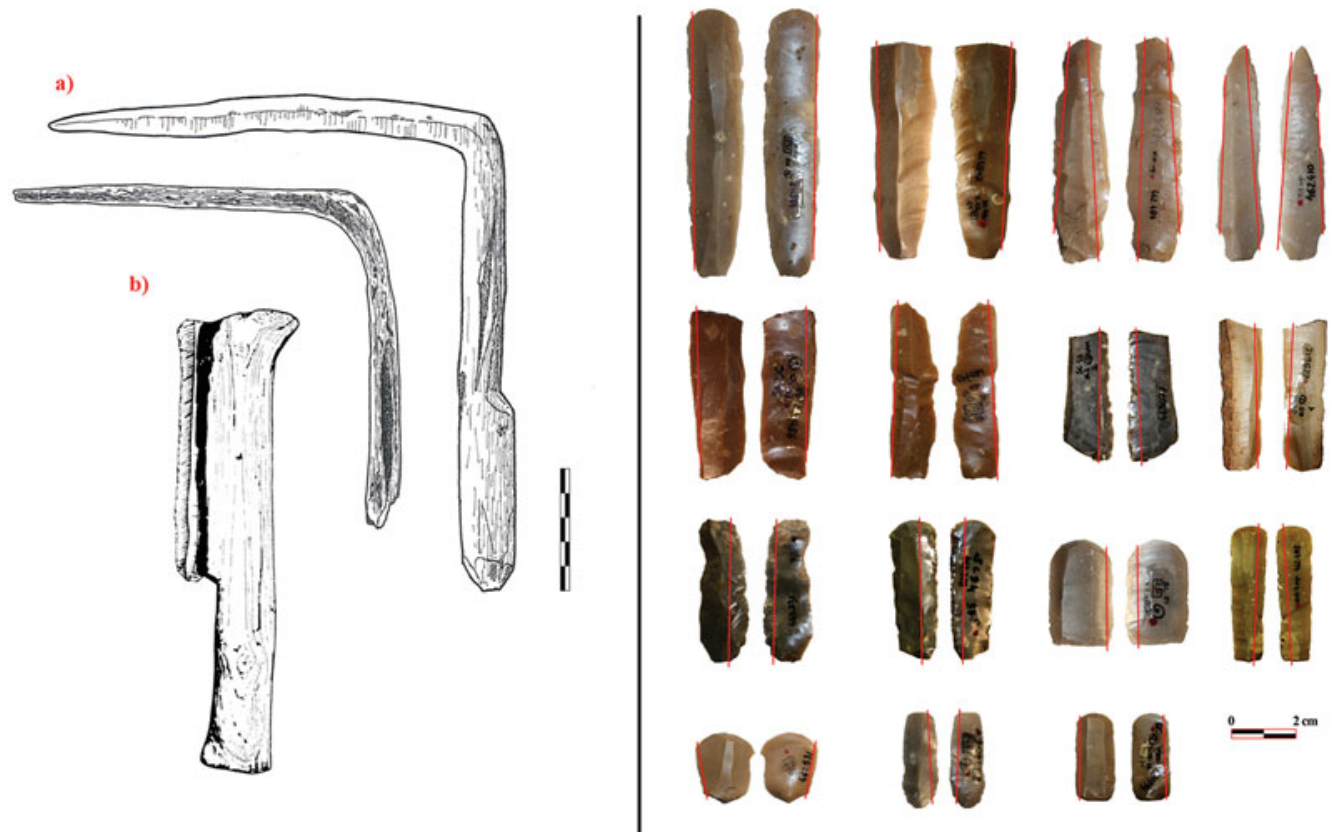

Figure 3. Examples of glossy blades for reaping knives, with: a) wooden sickle from La Draga (modified from Bosch et al. 2006); b) reaping knife from Auvernier-Port (modified from Egloff 1987).

(C) Antiquity Publications Ltd, 2017 
the Iberian Peninsula. At the same time, harvesting technologies underwent change and innovation during the course of their diffusion.

\section{Acknowledgements}

We would like to express our gratitude to colleagues participating in this project, who allowed and helped us to analyse the material at the heart of this study: D. Arobba, L. Baglioni, M. Baioni, P. Biagi, P. Boccuccia, F. Briois, M. Colombo, C. Conati Barbaro, S. Forenbaher, J. Guilaine, S. Kacar, C. Lemorini, C. Longhi, V. Leonini, D. Lo Vetro, F. Martini, D. Mengoli, P. Miracle, A. Moroni, I.M. Muntoni, C. Perlès, A. Pessina, E. Podrug, G. Radi, D. Radić, A.M. Ronchitelli, M. Serradimigni, P. Schirolli, E. Starnini, L. Sarti, G. Steffé, J. Tirabassi, C. Tozzi, A.M. Tunzi, P. Visentini, M. Venturino Gambari and B. Voytek.

\section{References}

Anderson, P.C. 1982. Comment préciser l'utilisation agricole des outils préhistoriques? Cahiers de I'Euphrate 3: 149-64.

Bosch, A., J. Chinchilla \& J. TARrús. 2006. Els objectes de fusta del poblat neolitic de La Draga. Excavacions 1995-2005 (Monografies del Centre d'Arqueologia Subaquàtica de Catalunya 6). Girona: Museu d'Arqueologia de Catalunya.

Colledge, S. \& J. Conolly (ed.). 2007. The origins and spread of domestic plants in Southwest Asia and Europe. London: Left Coast.

Egloff, M. 1987. Emmanchements du Néolithique à l'Âge du Bronze dans les palafittes d'Auvernier (lac de Neuchâtel), in La Main et l'Outil. Manches et emmanchements préhistoriques (Travaux de la Maison de l'Orient 15): 229-45. Lyon: Maison de l'Orient et de la Méditerranée Jean Pouilloux.

Gurova, M. 2014. Technological change. Some examples of technological change in prehistoric Bulgaria, in A. van Gijn, J. Whittaker \& P. Anderson (ed.) Exploring and explaining diversity in agricultural technology: 342-51. Oxford: Oxbow.

IbáÑez, J.J., I.C. Conte, B. Gassin, J.F. Gibaja, J. Gonzáles Urquijo, B. Márquez, S. Philibert \& A. Rodriguez. 2008. Harvesting technology during the Neolithic in south-west Europe, in L. Longo \& N. Skakun (ed.) Prehistoric technology 40 years later: functional studies and the Russian legacy (British Archaeological Reports International series 1783): 183-95. Oxford: Archaeopress.

Maeda, O., L. Lucas, F. Silva, K.I. Tanno \& D.Q. Fuller. 2016. Narrowing the harvest: increasing sickle investment and the rise of domesticated cereal agriculture in the Fertile Crescent. Quaternary Science Reviews 145: 226-37. https://doi.org/10.1016/j.quascirev.2016.05.032
Mascher, M., V.J. Schuenemann, U. Davidovich, N. Marom, A. Himmelbach, S. Hübner, A. Korol, M. David, E. Reiter, S. Riehl \& M. Schreiber. 2016. Genomic analysis of 6,000-year-old cultivated grain illuminates the domestication history of barley. Nature Genetics 48 : 1089-93. https://doi:10.1038/ng.3611

Mazzucco, N., J.F. Gibaja, A. Pessina \& J.J. Ibáñez. 2016. Reconstructing harvesting technologies through the analysis of sickle blades: a case study from Early-Middle Neolithic sites in northeastern Italy. Lithic Technology 41: 75-92. https://doi.org/10.1080/01977261.2016.1149654

Mercuri, A.M. 2014. Genesis and evolution of the cultural landscape in the Central Mediterranean: the 'where, when and how' through the palynological approach. Landscape Ecology 29: 1799-810. https://doi.org/10.1007/s10980-014-0093-0

Pessina, A. \& V. Tiné. 2008. Archeologia del Neolitico. L'Italia tra sesto e quarto millennio. Roma: Carocci.

Unger-Hamilton, R. 1984. The formation of use-wear polish on flint: beyond the 'deposit versus abrasion' controversy. Journal of Archaeological Science 11: 91-98. https://doi.org/10.1016/0305-4403(84)90044-X

Zanchetta, G., M. Bini, M. Cremaschi, M. Magny \& L. SADORI. 2013. The transition from natural to anthropogenic-dominated environmental change in Italy and the surrounding regions since the Neolithic: an introduction. Quaternary International 303: 1-9. https://doi.org/10.1016/j.quaint.2013.05.009 